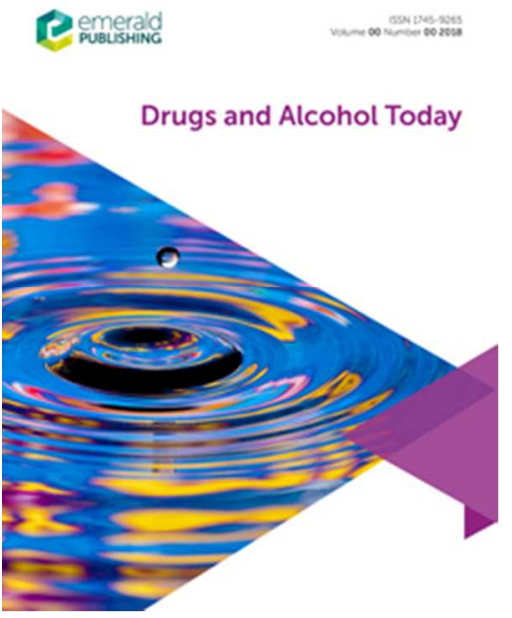

\title{
Introduction: cultivation, medication, activism and cannabis policy
}

\begin{tabular}{|r|l|}
\hline Journal: & Drugs and Alcohol Today \\
\hline Manuscript ID & DAT-03-2018-0014 \\
\hline Manuscript Type: & Policy Paper \\
\hline Keywords: & $\begin{array}{l}\text { Cannabis cultivation, Medical cannabis, Cannabis legalisation, Cannabis } \\
\text { activisim, social movements, patients voice }\end{array}$ \\
\hline
\end{tabular}

\section{SCHOLARONE ${ }^{\text {ix }}$ \\ Manuscripts}


Introduction: cultivation, medication, activism and cannabis policy

\author{
Cultivating cannabis in a cold climate
}

On Friday $23^{\text {rd }}$ February 2018 the medical cannabis bill introduced by UK Member of Parliament Paul Flynn ${ }^{1}$ went in for its second reading in the House of Commons. ${ }^{2}$ To the disappointment of several hundred activists assembled on the patch of green on Parliament Square in the freezing cold it never got to a vote, as the discussion on the preceding motion, Overseas Electors, dragged on.

The event captured many of the issues transforming the field of drug policy, at least as related to cannabis. A large number of demonstrators were middle aged, a few had rolled up in wheel chairs, and the police were keeping a respectful distance. Cannabis use in the UK, as in many other countries, has come of age, its respectability confirmed by the rising flow of scientific evidence of its therapeutic benefits. Politics, however, is out of step with scientific advances and changing social mores, held back by the counter weight of vested interests, the arrogance of political elites, and sheer inertia. Cannabis, whether for medical or non-medical use, remains illegal in the $\mathrm{UK}^{3}$, and most other countries, even as a growing number of jurisdictions change policy.

That very same week much media attention was given to the case of Alfie, a six year old boy from Kenilworth, England, suffering from epilepsy, who responded well to cannabis treatment. But in order to obtain medical quality cannabis legally, the family had had to move to the Netherlands. Now back in the UK, they are petitioning the Home Office to "grant him a licence to use cannabis oil to help soothe his symptoms" (Press Association, 2018). The government is considering the issue at the time of writing, and one of the mooted options is to include Alfie in a medical trial.

Unravelling the international system of controls that have been erected over the last fifty odd years is a daunting task, and perhaps the main reason why few governments have made any effort to correct what the UNODC reported in 2006 as an anomaly that is threatening to undermine the credibility of the international control system (UNODC, 2006: 186). There certainly was no appetite for change at Westminster, where the session ran out of time without the bill being heard.

Since policy makers are reluctant to lead on this issue, change has to come from below, driven by local and regional initiatives and a network of activists, growers and patients who are transforming the policy landscape. In the US eight states have now regulated cannabis production and sale for recreational and medical purposes, and a further 21 states have legal provision for medical cannabis only (Snapp and Herrera, 2018). Canada is planning to establish a similar model at national level this year. Uruguay's mixed approach - home-growing, state-provision of cannabis for purchase

\footnotetext{
${ }^{1}$ Legalisation of Cannabis (Medicinal Purposes) Bill 2017-19

2 Ten Minute Rule Bills are a type of Private Members' Bill that are introduced in the House of Commons under Standing Order No 23. The ten minute rule allows a backbench MP to make his or her case for a new Bill in a speech lasting up to ten minutes. An opposing speech may also be made before the House decides whether or not the Bill should be introduced. If the MP is successful the Bill is taken to have had its first reading.

${ }^{3}$ Some cannabis-derived medications are available for a limited number of conditions, as discussed below.
} 
through pharmacies, and Cannabis Social Clubs (CSCs) - is ground breaking as the first country (and a signatory of the UN conventions) to move towards a statemonitored regulated market (Hudak et al, 2018). Change is happening around the world - cannabis users and activists in other countries (including the UK) want to know 'Why not here?'

In Europe, quasi-legal retail markets have been in place for decades, such as the Dutch Coffeeshop system (Korf, 2008) and 'pusher street' in Cristiania, Copenhagen (Asmussen Frank, 2008). In many countries, such as Portugal, the Czech Republic and Germany, the possession of small quantities has been decriminalised (See Release, 2016 for decriminalisation policies across the globe). Even in the UK, a number of police forces give low priority to cannabis offences, to the chagrin of drug control advocates. Some UK Police and Crime Commissioners go even further, as Arfon Jones in North Wales, and Ron Hogg in Country Durham, have deprioritised pursuing cannabis consumers and small scale growers. Hogg has met with members of UKCSC chapters (Gayle, 2015), and more recently Jones has daringly expressed a desire to see cannabis regulated in a similar vein to alcohol (Brennan, 2018).

This street level pragmatism, of effective decriminalisation in some UK regions, has had significant social benefits. It has spared tens of thousands of people from being branded with a criminal record, as well as saving extensive criminal justice resources, yet it has only kicked the can down the proverbial road - or in this case, up the supply chain. In the Netherlands, it is known as the "back door problem". Cannabis, sold freely over the counters of hundreds of coffeeshops, is produced and delivered to the back door by organised crime groups (Boister, 2016). ${ }^{4}$ In the past, attempts by lawmakers to regulate cannabis supply have foundered on the uncompromising stipulations of the international drug control conventions and the opposition of EU partners in pursuit of 'harmonised' drug policies (Blickman, 2018; Boekhout van Solinge, 2017).

In fact, across Europe, drug policy has come to an impasse. Years of investment in the provision of harm reduction and treatment have been met with laudable success. The transmission rates of infectious diseases are down, with regional outbreaks, the rate of overdose deaths has stabilised and a large number of problem users are in contact with drug services (EMCDDA, 2018).

At the United Nations General Assembly Special Session on Drugs in 2016 (UNGASS), EU member states spoke with one voice in favour of humane, publichealth focused interventions, in full compliance with human rights. But tolerance and a 'human centred approach' do not mean legalisation, and nowhere has a ruling party committed to the regulation of cannabis markets (Chatwin, 2018).

It is therefore left to civil society, with the support of lower level governance agencies, to experiment with different approaches. As well as campaigning for legalisation whether for medical cannabis or for drug use more widely - users and sympathisers often engage in the illegal activities of cultivation and supply as well as possession and use. It is this activism, and the wider backdrop of cannabis policy change, that provides the focus of this special issue.

One model is CSCs, originally developed in Spain to provide members with a reliable supply, the opportunity for social use, and a modicum of protection from prosecution by pooling resources and sharing responsibility (Arana and Montañés Sánchez,

\footnotetext{
${ }^{4}$ A process that Francisco Thoumi, currently a member of the INCB, has called the cannabis' “immaculate conception" (Blickman, 2018).
} 
2011). Well established in parts of Spain, particularly the Basque country, Catalonia and Valencia, the model has since been transplanted to countries with a less benign legal environment, like Belgium (See the articles by Pardal; Ditchfield; Bone and de Hoedt but also Decorte, 2015).

A response, ironically, to changes in legislation in Holland that made it more difficult for Belgian visitors to purchase cannabis in coffeeshops close to the border, the growth of Belgian CSCs is perhaps one unexpected consequence of supply side intervention - a balloon effect. ${ }^{5}$ As Pardal explains in her contribution (see also Pardal 2016), the organisations remain small and operate in a hostile legal environment with an uncertain future. What they have demonstrated, however, is how dynamic the demand is for quality cannabis products and non-criminal supply sources.

Being able to source and distribute cannabis without making contact with the criminal market is also the major motivation for growers in New Zealand and Israel. The paper by Wilkins and Sznitman confirms previous work that firmly establishes domestic cultivation and 'social supply' as the dominant model. The chief motives of these growers - committing crimes of drug production and supply - are providing family and friends with quality product rather than to make profit.

The ambivalent situation of cannabis, now legal in Uruguay, parts of the US, and soon, Canada, widely consumed all over the world, but still controlled under the international conventions throws up a dilemma for a country like Jamaica. Here cannabis is deeply embedded in social and cultural history, a sacrament in the Rastafari religion, and a potent symbol in the anti-colonial struggle and rejection of Babylon and all things western (Bone, 2014).

Reform has been long in coming, with well-crafted proposals, such as the 2000 report of the Ganja Commission, being thrown off course by hostile response from the US ambassador. At the time, US governments were pursuing an aggressive drug control policy in the Caribbean (Klein, 2004).

But changes in legislation at state level have allowed US companies to develop products, assume economies of scale, and position themselves as industry leaders, while competitors in other countries are held in check by controls that the US government enforces. ${ }^{6}$ Only with a change in the US approach to regional drugs policy under the less interventionist Obama presidency did the Jamaican government get some space for policy experimentation. In this issue Machel et al discuss the reforms that are preparing the way to what the authors call the Caribbean Cannabis economy. But the mooted shift towards a commercial cannabis market is fraught with anxiety over the displacement that the influx of foreign capital would effect, and frustrations over the slow pace of work of the Cannabis Licensing Agency.

In Jamaica, at least, cannabis cultivators have found a voice and are getting organised. In most parts of the world the call for change comes from consumers, who lobby political representatives, organise marches and run other forms of civil protests. There is an activism at work here, a use of symbols and the mobilisation of

\footnotetext{
5 Though, as noted by Decorte (2015) the emergence of CSCs in Belgian coincided with a relaxation of their cannabis laws. In 2005 a joint guideline issued by the College of Public Prosecutors and the Minister of Justice called for the lowest prosecution priority to be given to cannabis possession by adults for quantities which did not exceed three grams or one cultivated female cannabis plant.

${ }^{6}$ The International Narcotics Control Strategy Report (INCSR) is delivered annually by the Department of State to Congress. It describes the efforts of key countries to attack all aspects of the international drug trade and may lead to sanctions on countries that are seen as not fulfilling their obligations.
} 
supporters around a specific issue, that both Guerra and Pardal for Mexico and Belgium respectively describe as social movements. Guerra's definition, of participants coordinating public representations of "worthiness, unity, numbers, and commitments" applies equally to the protesters at Westminster.

Of course, many of the consumers driving change in cannabis policy confound societal perceptions and fears of the 'drug taker'. They use cannabis not from addiction, the search for pleasure or oblivion but in order to control pain, fight nausea or keep any of a number of medical conditions in check. Cannabis, is a drug, in the historical sense of the word, in that it has medicinal properties and can be therapeutic or noxious depending on dosage. In the $19^{\text {th }}$ century the term 'drugs' referred to remedies concocted by apothecaries and prescribed by physicians (Porter, 1996). ${ }^{8}$ With the advances in organic chemistry in the late $19^{\text {th }}$ and the early $20^{\text {th }}$ century cannabis, like many other natural substances, was pushed aside by pharmaceutical medications. Over the last thirty years, however, it has been making a comeback, and lawmakers are reluctantly aligning legislation with changing medical perceptions.

So far, only a handful of European countries have been developing systems for the production and prescription of cannabis flowers: The Netherlands (2003), the Czech Republic (2013), Italy, Croatia (both 2015), Germany and Poland (both 2017). But the journey from repression towards a regulatory system is fraught with difficulties, as shown by Grotenhermen in his account of German cannabis legislation. The process for patient and medical practitioner is cumbersome, and health insurance companies often refuse to reimburse the costs.

\section{Medical activism}

Most countries still have a long way to travel before even engaging with this level of problem. The UK government has been skirting the issue, by allowing one producer, GW Pharmaceuticals, to market Sativex (an oromucosal spray) that can be prescribed for treating MS-related spasticity where patients do not respond to other treatments. Yet, the cost and limited application of Sativex places the medicine effectively out of reach of most patients who continue to rely largely on the criminal market. As Ditchfield and Godfrey detail in their accounts, this is often a painful experience, involving hard encounters with the criminal justice system and constant uncertainty over the reliability and quality of the medicine.

Many medical users have therefore started growing for peace of mind and an easier life. In some cases, it was simple desperation, as Bone and de Hoet lay out in the personal narrative of one patient with a serious case of Crohn's disease. This is the story of a long journey into cultivation and activism inspired by international regulatory models and US activists in particular. Several US states, including Colorado and California, have upended the legal situation and emerged as world leaders in the development of cannabis based products. In other instances, the emphasis has been on helping others (Ditchfield), but all growers and users

\footnotetext{
${ }^{7}$ For an in depth look into the prejudices and fears surrounding people who use drugs see: The Global Commission on Drugs, 2017 <http://www.globalcommissionondrugs.org/wpcontent/uploads/2018/01/GCDP-Report-2017_Perceptions-ENGLISH.pdf> 8 It has even been suggested that Queen Victoria used cannabis medically (Mills, 2003).
} 
encounter risks, including the malevolence and manipulation observed by Fry, and it is important to note that the US too have not yet established a workable model.

Activists will therefore continue generating evidence to build the case for policy reform. Medical consumers are playing a key role as legalisation for medical use has been seen as a precursor to legalisation for recreational use (Kilmer and MacCoun, 2017).

They will also have to reconcile dramatically different approaches to realising the aspired cannabis economy. On the one hand there is the sharing, not for profit, model exemplified by the best examples of the CSCs, or the apomedication networks (Klein and Potter, 2018) of cannabis healers that are becoming alternative forms of healthcare provision. Bypassing markets and medical establishments these shifts towards autarchy and the sharing economy somehow reconnects cannabis with the counter cultural protests of the 1960s. Developing a sharing economy from the grassroots poses a challenge to traditional regulatory thought, where cannabis is controlled by the government, the free market and/or the medical establishment. Regulatory power is devolving to local, social movements here, which facilitates a greater level of individual control over the cannabis production and distribution process. This allows consumers to create and shape their own cannabis culture, reminiscent of the anti-authoritarian movements in the 1960s.

On the other hand, the influx of capital from profit-oriented commercial corporations are piling into this potential market. Organisations such as Leafly are already developing sophisticated lobbying operations, using public relations to target policy makers and opinion formers. The objective is to open a market for a commodity, not to facilitate - home growing, healing and community - the 'cannabis culture' or ethos that is being promoted by the personal narratives of the activists and medical consumers in this special issue.

It is likely that the community will remain divided in its attitude. And while the 'small is beautiful' ethos has a lot of merit for product innovation, authenticity and for allowing a cottage industry type of control there are clear limitations. Advances in the demonstrable efficacy of cannabis medication require the controlled conditions, including of the cannabis input, that at present only large scale pharmaceutical enterprises can provide. Furthermore, cannabis online markets abound with opportunists and downright fraudsters, preying on the desperation of patients or the confusion of operators in a poorly regulated environment. Similarly, some CSCs refuse to follow the not for profit model, and are operating as 'shadow clubs' (Decorte, 2015: 128), selling cannabis strains for extortionate amounts, exploiting both medical and non-medical consumers alike.

\section{Coming in from the cold}

Some of the organisations behind the parliamentary protest, like the United Patients Alliance who are now spearheading the medical reform movement in the UK, are open in their support for commercial players. Others are reluctant, and fear that legislative change, if it does come, will only facilitate corporate profit, without establishing the right to grow your own. For instance, the UKCSC (2016), who advocate for medical and non-medical use, have established a 'Right2Grow' campaign, which emphasises the right to grow, share and collectively consume cannabis.

In any event, both these advocacy groups recognise the importance of telling human stories to allow change and they both followed Alfie's story all the way to the protest 
at Parliament on the $23^{\text {rd }}$ of February 2018. Four of the articles in this special issue are authored by cannabis activists or medical consumers, with Godfrey, Bone and De Hoedt, and Fry going even further, offering a personal narrative of their own cannabis journeys. This special issue is therefore unique in the drug policy field, since it incorporates non-academic perspectives and narratives within an academic journal.

Telling these human stories facilitates knowledge production by inputting cannabis consumer experiences into the evidence base. Policy scientists, communication scholars, psychologists and other social scientists are beginning to recognise the importance of telling good stories, to appeal to the emotions of policy makers and to the general public (Davidson, 2017). Although presenting the evidence is vital, finding reform champions and telling stories engages people on an emotive, human level, which speaks to their values (Rolles, 2016).

This is especially important for those researchers questioning 'evidence based policy' (EBP) - what the concept of 'evidence' even means, and who gets to speak authoritatively (see Lancaster et al, 2017a; 2017b; Ritter, Lancaster and Diprose, 2018 on the 'EBP' paradigm in drug policy) - since important policy debates cannot be answered by simply turning to the evidence (Davidson, 2017). Policy decision making invariably involves questions of values - of how the world 'ought to be' as opposed to relying solely on the facts. Arguing from a position of moral authority alongside the evidence makes the reform position stronger.

Alfie's story could be a game changer. More than 370,000 people have signed a petition since hearing his plight, calling for the Home Office to grant a special licence to allow him to use medical cannabis (BBC, 2018). Appealing to policy makers' and the publics' morality and values could facilitate legal change. Whichever way the change comes for Alfie, (via the sharing economy or via corporations), as for many other patients, it cannot come fast enough.

\section{References}

Arana, X. and Montañés Sánchez, V. (2011) 'Cannabis cultivation in Spain - the case of cannabis social clubs', In T. Decorte, G. Potter, and M. Bouchard (eds.) World Wide Weed. The Globalisation and Localisation of Cannabis Cultivation. London: Routledge.

Asmussen Frank, V. (2008) Danish drug policy - shifting from liberalism to repression. / Asmussen Frank, Vibeke: Drugs and Alcohol Today, Vol. 8, No. 2, 2008, p. 26-33.

BBC, (2018) 'Alfie Dingley's medical cannabis petition handed to government' http://www.bbc.co.uk/news/health-43459220

Blickman, T. (2018) 'The Elephant in the Room Cannabis in the international drug control regime'. In A. Klein and B. Stothard (eds.) Collapse of the global order on drugs? From UNGASS 2016 - to the High Level Review 2019. Bradford: Emerald.

Boekhout van Solinge, T. (2017) 'The Dutch Model of Cannabis Decriminalization and Tolerated Retail'. In E. Savona, M. Kleiman and F. Calderoni (eds.) Dual Markets: Comparative Approaches to Regulation, Springer, pp. 145-170. 
Boister, N. (2016) 'Waltzing on the Vienna Consensus on Drug Control? Tensions in the International System for the Control of Drugs,' Leiden Journal of International Law. 29: 389-409.

Bone, M. (2014) 'From the Sacrilegious to the Sacramental: A Global Review of Rastafari Cannabis Case Law'. In B.C. Labate and C. Cavnar (eds.) Prohibition, Religious Freedom, and Human Rights: Regulating Traditional Drug Use.

Berlin/Heidelberg: Springer.

Brennan, S. (2018) 'Police boss says off-licences should be able to sell drugs' WalesOnline. https://www.walesonline.co.uk/news/wales-news/police-bosssays-licences-should-14418936

Chatwin, C. (2018) 'The EU Position at UNGASS 2016' In A. Klein, and B. Stotard (eds.) Collapse of the global order on drugs? From UNGASS 2016 - to the High Level Review 2019. Bradford: Emerald

Davidson, B. (2017) 'Storytelling and evidence-based policy: lessons from the grey literature' Palgrave Communications.

https://www.nature.com/articles/palcomms201793.pdf

Decorte, T. (2015) 'Cannabis social clubs in Belgium: Organizational strengths and weaknesses, and threats to the model' International Journal of Drug Policy 26(1): $122-130$.

EMCDDA [European Monitoring Centre for Drugs and Drug Addiction] (2018) European Drugs Report: Trends and Developments. Lisbon: EMCDDA.

Gayle, D. (2015) 'Durham police stop targeting pot smokers and small scale growers' The Guardian $25^{\text {th }}$ July 2015. https://www.theguardian.com/society/2015/jul/22/durham-police-stoptargeting-pot-smokers-and-small-scale-growers

The Global Commission on Drugs (2017) The world drug perception problem: countering prejudices about people who use drugs http://www.globalcommissionondrugs.org/wp-content/uploads/2018/01/GCDPReport-2017_Perceptions-ENGLISH.pdf

Hudak, J., Ramsey, G. and Walsh, J. (2018) Uruguay's cannabis law: Pioneering a new paradigm. WOLA

Ingold, J. (2018). 'Jeff Sessions' latest memo pushes prosecutors to seek the death penalty against big drug dealers. That could include legal marijuana business owners'. Denver Post $22^{\text {nd }}$ March 2018. https://www.denverpost.com/2018/03/22/jeff-sessions-death-penalty-memodrug-dealers-marijuana/

Kilmer, B. and MacCoun, R.J. (2017) 'How medical marijuana smoothed the transition to marijuana legalization in the United States' Annual Review of Law and Social Science 13: 181-202.

Klein, A. and Potter, G. (2018) 'The three betrayals of the medical cannabis growing activist: from multiple victimhood to reconstruction, redemption and activism' International Journal of Drug Policy. 53: 65-72. 
Korf, D. J. (2008) 'An open front door: the coffee shop phenomenon in the Netherlands'. In S. Rödner Snitzman, B. Olsson, \& R. Room (Eds.), A cannabis reader: global issues and local experiences (pp. 137-154). (EMCDDA Monographs; No. 8). Lisbon: EMCDDA.

Lancaster, K., Seear, K., Treloar, C. and Ritter, A. (2017a) "The productive techniques and constitutive effects of 'evidence-based policy' and 'consumer participation' discourses in health policy processes" Social Science \& Medicine, 176: 60-68.

Lancaster K;Treloar C; Ritter A, (2017b), "Naloxone works': The politics of knowledge in 'evidence-based' drug policy', Health (United Kingdom), vol. 21, pp. 278 294, http://dx.doi.org/10.1177/1363459316688520

Mills, J. (2003) Cannabis Britannica: Empire, Trade, and Prohibition 1800-1928, Oxford: OUP.

Pardal, M. (2016) 'Cannabis Social Clubs through the lens of the drug user movement.' Tijdschrift over Cultuur \& Criminaliteit, 6, 47-58

Porter, R, (1996) 'The history of the 'drugs problem" Criminal Justice Matters 24: 35.

Press Association (2018) 'Home Office considers cannabis oil trial to help boy with epilepsy.' The Guardian, $1^{\text {st }}$ March 2018.

Ritter, A., Lancaster, K. and Diprose, R. (2018) 'Improving drug policy: The potential of broader democratic participation', International Journal of Drug Policy, 55: 1-7.

Release (2016) A Quiet Revolution: Drug decriminalisation across the globe. London: Release.

https://www.release.org.uk/sites/default/files/pdf/publications/A\%20Quiet\% 20Revolution\%20-\%20Decriminalisation\%20Across\%20the\%20Globe.pdf

Rolles, S. (2016) NoNonsense Legalizing Drugs: The key to ending the war. Oxford: New Internationalist Publications.

UKCSC (2016) 'UKCSC National AGM'

Snapp, Z. and Herrera, J. (2018) 'U.S. Drug Policy: Flexible Prohibition and Regulation'. In A. Klein and B. Stotard (eds.) Collapse of the global order on drugs? From UNGASS 2016 - to the High Level Review 2019. Bradford: Emerald.

UNODC [United Nations Office for Drugs and Crime] (2006) World Drug Report. Vienna: UNODC. 